\title{
Anaplastic Ganglioglioma of the Pineal Region - A Case Report
}

\section{Ganglioglioma anaplásico da região da pineal - relato de caso}

\author{
Marcos Devanir Silva da Costa ${ }^{1}$ Ricardo Silva Centeno ${ }^{1}$ Mateus Reghin Neto ${ }^{2}$ \\ Hugo Leonardo Doria Netto ${ }^{2}$ Jose Maria Campos Filho ${ }^{2}$ Daniel de Araujo Paz ${ }^{1}$ \\ Thiago Pereira Rodrigues ${ }^{1}$ Bruno Augusto Telles ${ }^{2}$ Carmen Lucia Penteado Lancellotti ${ }^{3}$ \\ Sergio Cavalheiro ${ }^{1}$ Feres Chaddad-Neto ${ }^{1,2}$ \\ ${ }^{1}$ Department of Neurosurgery of Escola Paulista de Medicina - \\ UNIFESP, São Paulo, SP, Brazil \\ ${ }^{2}$ Instituto de Ciências Neurológicas, São Paulo, SP, Brazil \\ ${ }^{3}$ Department of Neuropathology of the Faculdade de Ciências \\ Address for correspondence Ricardo Silva Centeno, MD, PhD, \\ Department of Neurosurgery, Federal University of São Paulo, 715. \\ Napoleao de Barros Street, 6th floor, São Paulo, SP, Brazil 04024-002 \\ (e-mail: ricardoscenteno@gmail.com).
} Medicas da Santa Casa de São Paulo, São Paulo, SP, Brazil

Arq Bras Neurocir 2016;35:253-256.

\begin{abstract}
Keywords

- pineal gland

- brain tumor

- malignant ganglioglioma

Introduction Gangliogliomas are tumors commonly found in the temporal lobe and related to seizures; their appearance in the pineal region is rarely described. This report characterizes the first case of anaplastic ganglioglioma of the pineal region.

Case Report The authors describe the case of a 32-year-old woman that developed progressive headache. An MRI investigation revealed a pineal tumor. The patient tested negative for biomarkers and underwent surgery through supracerebellar infratentorial approach and achieved gross total resection of the tumor in a challenging location. Pathological analysis revealed a biphasic neoplasm with the following two distinct phenotypes in separate fields: an immature neuronal component with several atypical mitoses and a mature astrocytic component with bipolar cells, microcysts, and eosinophilic bodies. The Ki67/MIB1 proliferation index was $20-30 \%$ in localized hotspots. Based on the pathological findings, the tumor was defined as an anaplastic ganglioglioma World Health Organization (WHO) grade III.

Discussion/Conclusion Gangliogliomas are classified as glioneural neoplasms based on the histologic findings described as a mixture of neoplastic astrocytes and neurons. Moreover, these tumors represent $0.4-1.3 \%$ of tumors of the central nervous system. Authors describe de novo anaplastic ganglioglioma as $1 \%$ of the largest series. Gross total resection and adjuvant treatment may play important role in patients' prognostic. In this case, due to the malignant anaplastic component of her tumor, the patient received treatment with temozolamide and radiotherapy after gross total resection of the lesion.
\end{abstract}

received

June 29, 2015

accepted

August 7, 2015

published online

September 25, 2015
DOI http://dx.doi.org/

10.1055/s-0035-1564583. ISSN 0103-5355.
Copyright $@ 2016$ by Thieme Publicações License terms

Ltda, Rio de Janeiro, Brazil. 


\begin{abstract}
Resumo
Palavras-Chave

- glândula pineal

- neoplasias encefálicas

- ganglioglioma maligno

- região da pineal

Introdução Gangliogliomas são tumores comumente encontrados no lobo temporal e se relacionam com crises epilépticas; o aparecimento desses tumores na região da pineal é raramente descrito. Este relato caracteriza o primeiro caso de ganglioglioma anaplásico da região da pineal.

Relato de Caso Paciente do sexo feminino, 32 anos, apresentou-se com cefaleia de piora progressiva. Investigação com ressonância magnética revelou tumor na região da pineal. Os biomarcadores para tumores da pineal foram negativos e a paciente foi submetida a microcirurgia com o acesso supracerebelar e infratentorial atingindo ressecção total da lesão. A análise patológica revelou neoplasia bifásica com dois fenótipos distintos em campos separados: um componente era composto por células neuronais imaturas com inúmeras mitoses atípicas e o segundo componente era composto por astrócitos maduros, microcistos e corpos eosinofílicos. Foi encontrado um índice proliferativo Ki67/M1B1 de 20-30\%. Baseado nos achados anatomopatológicos, o tumor foi definido como ganglioglioma anaplásico grau III da OMS.

Discussão/Conclusão Gangliogliomas são classificados como neoplasias glioneurais baseado nos achados histológicos descritos como misto de neoplasia neuronal e glial; esses tumores representam $0,4-1,3 \%$ de todos os tumores do sistema nervoso central. Ganglioglioma anaplásico de novo tem sido descrido em $1 \%$ nas maiores series de gangliogliomas. Ressecção total da lesão e tratamento adjuvante desempenham um papel importante no prognóstico dos pacientes. Devido ao componente anaplásico do tumor em questão, a paciente foi tratada com temozolamida e radioterapia após ressecção total da lesão.
\end{abstract}

\section{Introduction}

Gangliogliomas represent only $0.4-1.3 \%$ of central nervous system neoplasms, ${ }^{1}$ and anaplastic gangliogliomas represent $3-5 \%$ of all gangliogliomas. ${ }^{2}$ Gangliogliomas are frequently found in the temporal lobe and are known to cause epilepsy. ${ }^{3}$ The occurrence of gangliomas in the pineal region has rarely been reported in the literature. This study reports on the first anaplastic ganglioglioma of the pineal region treated by surgery via the supracerebellar infratentorial approach.

\section{Case Report}

\section{History}

A 32-year-old woman developed symptoms of progressive headache over a 1-year period. There was no evidence of medication, alcohol, or tobacco use, and no history of previous diseases. The neurological examination yielded normal findings. Sagittal T1-weighted MRI revealed an ill-defined pineal mass with spontaneous hyperintense areas (-Fig. 1). Axial T2-weighted MRI revealed heterogeneous cystic and solid aspects of the lesion and a high intensity signal within the lesion. Post-contrast T1-weighted MRI revealed enhancement of the solid portion of the lesion. Levels of the tumor markers AFP and $\beta$-hCG were normal in both the cerebral spinal fluid (CSF) and serum.

\section{Surgery}

The patient underwent surgery in the sitting position via the supracerebellar infratentorial approach that allowed optimal visualization of the lesion. As demonstrated in the images (-Fig. 2), the tumor had both cystic and fibro-elastic regions that were completely resected during surgery.

\section{Pathological Findings}

Pathological analysis revealed a biphasic neoplasm with the following two distinct phenotypes in separate fields: an



Fig. 1 Preoperative MRI. Sagittal T1-weighted MRI showing an illdefined pineal mass with spontaneous hyperintense areas. 


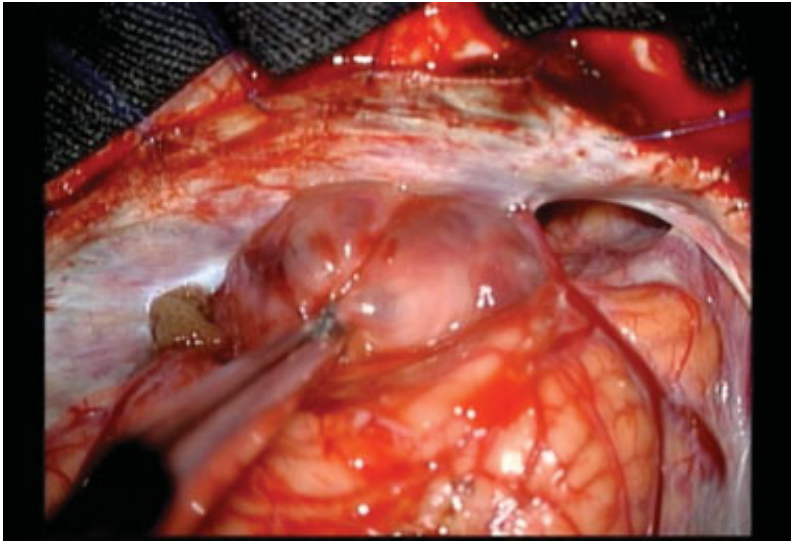

Fig. 2 Intraoperative images. Removal of the tumor via the infratentorial supracerebellar approach.

immature neuronal component with several atypical mitoses and a mature astrocytic component with bipolar cells, microcysts, and eosinophilic bodies ( - Fig. $\mathbf{3 A}$ and $\mathbf{B}$ ). The neuronal component was composed of synaptophysin-positive ganglion cells. The astrocytic component was GFAP positive. The neuronal component had undifferentiated areas with micropapillae, necrosis, and prominent endothelial proliferation. The tumor was negative for the markers AE1AE3, CK8, and chromogranin A. The Ki67/MIB1 proliferatiion index was $20-30 \%$ in localized hotspots. Based on the


Fig. 3 Biphasic neoplasm with microvascular proliferation. (A) Neuronal component, hematoxylin, and eosin (H\&E) stain, original magnification $200 \times(H \& E, 200 \times)$. (B) Astrocytic component with microcysts (H\&E, 200×). pathological findings, the tumor was defined as an anaplastic ganglioglioma WHO grade III.

\section{Postoperative Course}

On the fourth postoperative day, the patient was discharged from the hospital without any neurological deficits, and MRI grossly confirmed complete resection of the lesion ( - Fig. 4). The patient underwent chemotherapy with temozolamide and conformational radiotherapy at a dose of $56 \mathrm{cGy}$ in the tumor bed.

\section{Discussion}

Gangliogliomas represent $0.4-1.3 \%$ of central nervous system tumors. ${ }^{1}$ Luyken et al. studied supratentorial gangliogliomas in 184 patients and found a predominance of tumors in the temporal lobe (79\%), particularly in the temporomesial region (50\%). ${ }^{4}$ The study reported two $(1.0 \%)$ cases of de novo anaplastic ganglioglioma and 3\% recurrence during followup time, including three cases of malignant progression, although none were in the pineal region. Previously, only 10 cases of pineal ganglioglioma had been published; however, this is the first report in literature describing a de novo anaplastic ganglioglioma in the pineal region.

Gangliogliomas are classified as glioneural neoplasms, based on histologic findings described as a mixture of neoplastic astrocytes and neurons. The specific immunoreactivity to glial fibrillary acidic protein (GFAP), synaptophysin, and neurofilament protein demonstrate a dual origin of the cells. Usually both components are benign, and the tumor



Fig. 4 Postoperative MRI. A: Sagittal T1-weighted MRI demonstrating gross total resection. 
is classified as WHO Grade I or II. Rarely, a tumor contains areas with mitotic activity, anaplasia, and necrosis, characterizing it as a high-grade tumor. ${ }^{2,5,6}$ Moreover, some authors use the presence of anaplastic histologic features or a MIB-1 labeling index $>10 \%$ to define a high-grade tumor. ${ }^{2,4,6,7}$

The diagnosis of ganglioglioma by using neuroimaging (computed tomography and MRI) is mainly dependent on the delineation of a solid or partially cystic mass. ${ }^{8,9}$ There are focal calcifications in 35\% of tumors and enhancement with contrast material in $50 \% .^{5,8,9}$ The signal intensity is non-specific and it is usually heterogeneously hyperintense on T2-weighted images, while iso- or hypointense on T1-weighted images. ${ }^{9,10}$ Most gangliogliomas show some contrast enhancement; however, there are too few cases of anaplastic ganglioglioma to establish parameters to differentiate the low- and high-grade categories. ${ }^{11}$

The relationship between pineal ganglioglioma and tumor markers seems to be nonspecific, as only two reports have documented serum AFP and $\beta$-hCG, and no reports have documented CSF markers. Tokoro et al. ${ }^{12}$ reported a single case of ganglioglioma with elevated serum AFP level. However, Chang ${ }^{4}$ described a female patient with premature thelarche related to a pineal ganglioglioma for which serum AFP and $\beta$-hCG levels were normal. In the present case, serum, and CSF marker levels were normal.

Surgery plays an important role in the treatment of gangliogliomas. Luyken et al. ${ }^{4}$ reported a 7.5 -year recurrence-free survival rate of $97 \%$ in a series with $79 \%$ of gross total resection, only 5 patients had tumor recurrence between 7 months and 3 years after surgery, and 3 (2\%) of these patients had histologic signs of malignant progression, including 2 patients who had histologically confirmed glioblastoma. Lang et al., ${ }^{13}$ described a 5-year and 10 -year survival rate of $89 \%$ and $84 \%$, respectively, and a recurrence rate of $16 \%$ in supratentorial gangliogliomas that underwent subtotal resection. In a review, DeMarchi et al. $^{2}$ reported a worse prognosis for anaplastic gangliogliomas treated with surgery alone. However, there is insufficient data supporting the indications and timing for radiotherapy and chemotherapy. ${ }^{2,6}$ Scoccianti et al. ${ }^{6}$ reported an indication for conformal radiotherapy to the operative bed plus a $10-\mathrm{mm}$ safety margin. In the present case, we employed adjuvant therapy based on current treatment standards for other high-grade gliomas aimed at an extended recurrence-free survival.

\section{Conclusion}

This report describes a very rare case of a 32-year-old woman with anaplastic ganglioglioma of the pineal region, which tested negative for biomarkers. The surgical approach achieved gross total resection of the tumor in a challenging location. However, given the rarity of anaplastic gangliogliomas, there is a lack of information regarding adjuvant treatment.

\section{References}

1 Kalyan-Raman UP, Olivero WC. Ganglioglioma: a correlative clinicopathological and radiological study of ten surgically treated cases with follow-up. Neurosurgery 1987;20(3):428-433

2 DeMarchi R, Abu-Abed S, Munoz D, Loch Macdonald R. Malignant ganglioglioma: case report and review of literature. J Neurooncol 2011;101(2):311-318

3 Fagundes-Pereyra WJ, Sousa Ld, Carvalho GT, Sousa AA. Ganglioglioma of the pineal region: case report. Arq Neuropsiquiatr 2001;59(3-A):599-604

4 Luyken C, Blümcke I, Fimmers R, Urbach H, Wiestler OD, Schramm J. Supratentorial gangliogliomas: histopathologic grading and tumor recurrence in 184 patients with a median follow-up of 8 years. Cancer 2004;101(1):146-155

5 Faillot T, Sichez JP, Capelle L, Kujas M, Fohanno D. Ganglioglioma of the pineal region: case report and review of the literature. Surg Neurol 1998;49(1):104-107, discussion 107-108

6 Scoccianti S, Giordano F, Agresti B, et al. Pediatric primary anaplastic ganglioglioma: a case report and review of the literature. Pediatr Neurosurg 2012;48(1):35-41

7 Rades D, Zwick L, Leppert J, et al. The role of postoperative radiotherapy for the treatment of gangliogliomas. Cancer 2010; 116(2):432-442

8 Dorne HL, O'Gorman AM, Melanson D. Computed tomography of intracranial gangliogliomas. AJNR Am J Neuroradiol 1986;7(2): 281-285

9 Castillo M, Davis PC, Takei Y, Hoffman JC Jr. Intracranial ganglioglioma: MR, CT, and clinical findings in 18 patients. AJNR Am J Neuroradiol 1990;11(1):109-114

10 Zentner J, Wolf HK, Ostertun B, et al. Gangliogliomas: clinical, radiological, and histopathological findings in 51 patients. J Neurol Neurosurg Psychiatry 1994;57(12):1497-1502

11 Kang DH, Lee CH, Hwang SH, Park IS, Han JW, Jung JM. Anaplastic ganglioglioma in a middle-aged woman: a case report with a review of the literature. J Korean Med Sci 2007;22(Suppl):S139-S144

12 Tokoro K, Chiba Y, Ohtani T, Abe H, Yagishita S. Pineal ganglioglioma in a patient with familial basal ganglia calcification and elevated serum alpha-fetoprotein: case report. Neurosurgery 1993;33(3):506-511, discussion 511

13 Lang FF, Epstein FJ, Ransohoff J, et al. Central nervous system gangliogliomas. Part 2: Clinical outcome. J Neurosurg 1993;79(6):867-873 